\title{
Plant colonization, succession and ecosystem development on Surtsey with reference to neighbouring islands
}

\author{
B. Magnússon ${ }^{1}$, S. H. Magnússon ${ }^{1}$, E. Ólafsson ${ }^{1}$, and B. D. Sigurdsson ${ }^{2}$ \\ ${ }^{1}$ Icelandic Institute of Natural History, Urriðaholtsstræti 6-8, P.O. Box 125, 220 Garðabær, Iceland \\ ${ }^{2}$ Agricultural University of Iceland, Hvanneyri, 311 Borgarnes, Iceland \\ Correspondence to: B. Magnússon (borgthor@ni.is)
}

Received: 31 March 2014 - Published in Biogeosciences Discuss.: 17 June 2014

Revised: 29 August 2014 - Accepted: 4 September 2014 - Published: 9 October 2014

\begin{abstract}
Plant colonization and succession on the volcanic island of Surtsey, formed in 1963, have been closely followed. In 2013, a total of 69 vascular plant species had been discovered on the island; of these, 59 were present and 39 had established viable populations. Surtsey had more than twice the species of any of the comparable neighbouring islands, and all of their common species had established on Surtsey. The first colonizers were dispersed by sea, but, after 1985, bird dispersal became the principal pathway with the formation of a seagull colony on the island and consequent site amelioration. This allowed wind-dispersed species to establish after 1990. Since 2007, there has been a net loss of species on the island. A study of plant succession, soil formation and invertebrate communities in permanent plots on Surtsey and on two older neighbouring islands (plants and soil) has revealed that seabirds, through their transfer of nutrients from sea to land, are major drivers of development of these ecosystems. In the area impacted by seagulls, dense grassland swards have developed and plant cover, species richness, diversity, plant biomass and soil carbon become significantly higher than in low-impact areas, which remained relatively barren. A similar difference was found for the invertebrate fauna. After 2000, the vegetation of the oldest part of the seagull colony became increasingly dominated by long-lived, rhizomatous grasses (Festuca, Poa, Leymus) with a decline in species richness and diversity. Old grasslands of the neighbouring islands Elliðaey (puffin colony, high nutrient input) and Heimaey (no seabirds, low nutrient input) contrasted sharply. The puffin grassland of Elliðaey was very dense and species-poor. It was dominated by Festuca and Poa, and very similar to the seagull grassland developing on Surtsey. The Heimaey grassland was significantly
\end{abstract}

higher in species richness and diversity, and had a more even cover of dominants (Festuca/Agrostis/Ranunculus). We forecast that, with continued erosion of Surtsey, loss of habitats and increasing impact from seabirds a lush, species-poor grassland will develop and persist, as on the old neighbouring islands.

\section{Introduction}

The frequent volcanic eruptions in Iceland cause regular disturbance and ecosystem regression (Arnalds, 2013). In the more severe eruptions, existing biota and ecosystems are lost and new surfaces created; thereafter, colonization and primary succession commence. The numerous lava flows around Mt. Hekla in the south of the country have provided excellent opportunities for chronosequence studies of plant colonization and community development (Bjarnason, 1991; Cutler et al., 2008; Cutler, 2010), comparable to studies around active volcanoes in temperate and tropical regions. The 1963 submarine eruption and birth of Surtsey island off the southern coast of Iceland was, however, a surprise. The volcanic origin of the Vestmannaeyjar islands was known, but the previous eruptions in the system had occurred over 5000 yr ago (Sigurðsson and Jakobsson, 2009). The Surtsey eruption, soon followed by the Heimaey eruption in 1973, set a new focus on the islands and extensive geological and biological research was initiated (Lindroth et al., 1973; Friðriksson, 1975; Friðriksson and Magnússon, 1992; Jakobsson et al., 2007; Svavarsdóttir and Walker, 2009). Only a few volcanic islands have recently emerged, including Anak Krakatau (1927) in Indonesia, Tuluman Island (1953) 
in New Guinea, Surtsey (1963) and Motmot (1968) in Lake Wisdom on Long Island in New Guinea (Thornton, 2007). Surtsey is a crucial example because of the unbroken record of monitoring and strict protection of the island, which has minimized human interferance (Svavarsdóttir and Walker, 2009). The studies on Surtsey are comparable to the longterm monitoring at Mount St. Helens volcano in Washington, USA, following the eruption of 1980 (Dale et al., 2005; del Moral, 2009; del Moral and Magnússon, 2014). More recent eruptions around the world have evoked interest, and new studies of their ecological effects and recovery have commenced. These include those of Kastatochi in the Aleutian Islands, which erupted in 2008 (DeGange et al., 2010).

The Vestmannaeyjar islands are very young on geological and evolutionary timescales. Aside from their volcanic origin, they have little in common with island complexes commonly cited in island biogeography (Whittaker et al., 2008). However, the recent Surtsey and Heimaey eruptions and their neighbouring islands with different degrees of erosion and ecosystem development give a unique opportunity to understand the rise and fall of oceanic islands. The rate of development on Surtsey has been faster than anticipated. From its birth, the island has lost half of its area due to heavy oceanic erosion (Jakobsson et al., 2007). In the colonization of the island, seagulls have come to play a key role in seed dispersal and nutrient transfer from sea to land, essential for ecosystem development (Magnússon et al., 2009; Sigurdsson and Magnusson, 2010; del Moral and Magnússon, 2014; Leblans et al., 2014). These islands harbour some of the largest seabird colonies of the North Atlantic (Hilmarsson, 2009; Hansen et al., 2011), which greatly affect the vegetation and ecosystem structure. On Surtsey, it has, for the first time, been possible to follow the initial steps of colonization and primary succession of these subarctic volcanic islands. As outlined by Svavarsdóttir and Walker (2009), the detailed studies carried out on Surtsey are of particular value due to their long-term data, detailed demographic data, information on species interactions and responses to nutrient inputs, opportunities to test island biogeography concepts, and more.

In this paper, we describe plant colonization of Surtsey starting with the discovery of the first plant in 1965, and report a permanent plot study initiated in 1990. This study is among the very few to comprehensively follow the simultaneous development of vegetation, soil and invertebrate communities. Then, we present results from permanent plots newly established on neighbouring islands. The general objectives of our studies are to follow plant colonization and ecosystem development on Surtsey under different nutrient loads from seabirds, and compare this to the biotas and ecosystems of the neighbouring islands that are several thousands of years older.

\section{Methods}

\subsection{Study area}

Surtsey $\left(63^{\circ} 18^{\prime} \mathrm{N}, 20^{\circ} 36^{\prime} \mathrm{W}\right)$ is in the Vestmannaeyjar archipelago, which consists of 18 small islands (from $0.001-$ $13.4 \mathrm{~km}^{2}$ in size). They are within a small area of $25 \times 25 \mathrm{~km}$ and only $7-35 \mathrm{~km}$ from the southern coast of Iceland (Fig. 1). These islands form a young volcanic system with the oldest rock formations dating from 40000 years BP. During the Holocene, volcanism has remained at a low frequency in the Vestmannaeyjar system (Sigurðsson and Jakobsson, 2009). Surtsey, the southernmost of the islands, was formed during a volcanic eruption that lasted from November 1963 to June 1967, when the island had reached an area of $2.7 \mathrm{~km}^{2}$ and a height of $173 \mathrm{~m}$ a.s.l. During the eruption, large tephra cones were formed in explosive phases of the two main central craters. The cones were gradually transformed into denser palagonite tuff (Jakobsson et al., 2000). The southern part of Surtsey consists of lava flows from the craters. Following the eruption, the rough lava was gradually filled in by drifting tephra from the craters, except for the southeasternmost part of the island, where airborne dust has settled. The northern part is a low spit formed by eroded coastal sediments deposited on the leeward side. The spit is flooded by surf in extreme winter storms. Coastal erosion has taken a heavy toll of the island and by 2012 it had been reduced by half, to an area of $1.3 \mathrm{~km}^{2}$. The most extensive erosion has occurred on the southern and southwestern part, where high sea cliffs have been cut into the lava shield and palagonite tuff (Jakobsson et al., 2007). Surtsey is still the second-largest island after Heimaey. Following Surtsey in size are Elliðaey $\left(0.46 \mathrm{~km}^{2}\right)$ and Bjarnarey $\left(0.32 \mathrm{~km}^{2}\right)$ to the northeast and leeward of Heimaey. Erosion will probably leave Surtsey resembling the unprotected neighbouring islands of Geirfuglasker, Súlnasker, Geldungur and Hellisey $\left(0.02-0.13 \mathrm{~km}^{2}\right)$ that also lie unsheltered in the open ocean (Fig. 1).

The climate of the Vestmannaeyjar area is mild and oceanic. At the Heimaey weather station, the mean annual temperature during $1963-2012$ was $5.1^{\circ} \mathrm{C}$ and the mean annual precipitation $1599 \mathrm{~mm}$ (Icelandic Meteorological Office). Waters off the southern coast of Iceland are productive and rich in marine life (Astthorsson et al., 2007), and seabirds are particularly abundant (Hilmarsson, 2009). The Vestmannaeyjar islands are the home to large breeding populations of Atlantic puffin (Fratercula arctica), northern fulmar (Fulmarus glacialis), manx shearwater (Puffinus puffinus), storm petrel (Hydrobates pelagicus), Leach's petrel (Oceanodroma leucorhoa), gannet (Morus bassanus), kittiwake (Rissa tridactyla), common guillemot (Uria aalge), razorbill (Alca torda) and black guillemot (Cepphus grylle); bird nomenclature follows the British Ornithologists' Union (BOU) (2013). The seabirds impact the vegetation with their nutrient transfer from sea to land, burrowing, nest building and through 


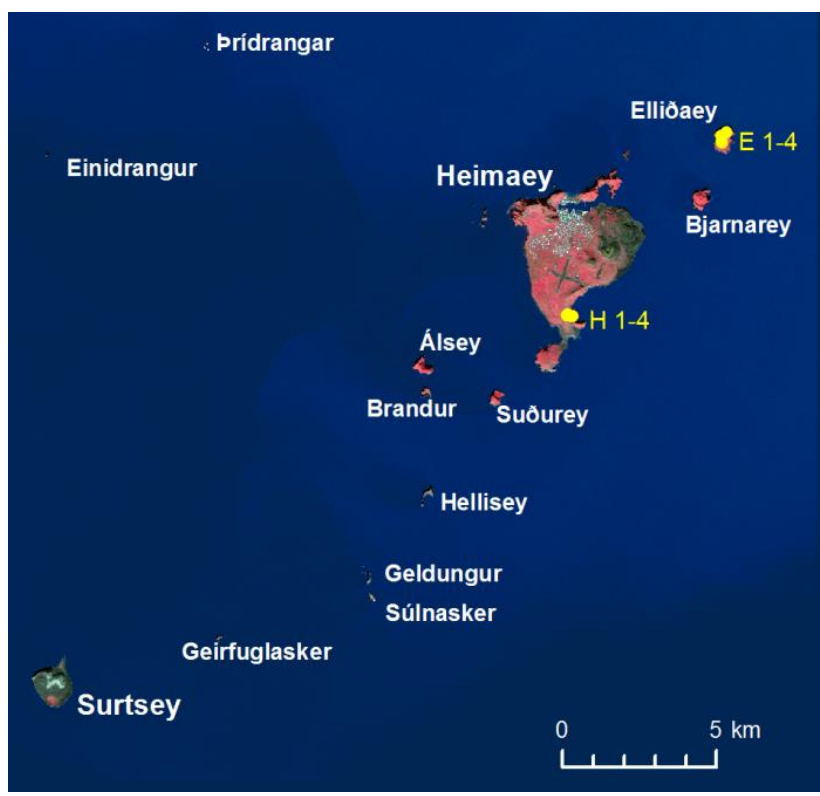

Figure 1. Surtsey and other Vestmannaeyjar islands on an infrared Rapid Eye image from 28 August 2012. Areas with dense vegetation appear in red colour, e.g. gull colony on Surtsey. Location of vegetation plots sampled on Elliðaey and Heimaey in 2013 is shown in yellow.

other activities. A few species of heathland birds also breed on the islands, but their density is low (Hilmarsson, 2009).

The vascular flora of the Vestmannaeyjar islands contains some 160 species, and all but a few are present on Heimaey. The other old islands harbour only $2-28$ species, corresponding to their size. The most diverse vegetation is also found on Heimaey, which has beach, heathland, herb slope, dry meadow, seabird grassland and coastal cliff communities. On the other islands, lush seabird grasslands and cliff communities are the main vegetation types. The dominants of the grasslands are the rhizomatous grasses Festuca rubra and Poa pratensis. Among common species of the cliffs are Cochlearia officinalis, Puccinellia capillaris and Armeria maritima (Friðriksson and Johnsen 1967; Friðriksson, 1975); plant nomenclature follows Kristinsson (2008).

Heimaey has been impacted by human inhabitation and livestock grazing since the ninth century. The larger surrounding islands and some of the smaller ones have also been grazed by sheep since early times (Eyjólfsson, 2009).

\subsection{Plant colonization and survival on Surtsey}

Surtsey has annually been studied by biologists since 1964 . During each visit, all portions of the island are thoroughly searched to update survival and colonization of vascular species. This provides an unbroken and unparalleled record of plant colonization from 1965, when the first plant was found on the island, to the present. Exact locations of the first colonists are known, as are their probable routes of disper- sal, propagation and spread of survivors (Friðriksson, 1975, 2000; Magnússon et al., 2009). Separate studies of lichen (Kristinsson and Heiðmarsson, 2009) and bryophyte (Magnússon and Friðriksson 1974; Ingimundardóttir et al., 2014) colonization have also been conducted.

\subsection{Study in permanent plots}

Plant succession has been studied in permanent plots on Surtsey since 1990, when the first plots were established. The location of the plots was chosen subjectively with respect to substrate type and influence of seagulls on vegetation development on the island. The first plots were set out in the center of the developing gull colony on bare and sandy lava. Following this, plots were also established under comparable substrate conditions on other parts of the island in areas where there were signs of plant colonization. Plots were not established in areas where no colonization had occurred at the time, e.g. on the solid palagonite ridges (Magnússon et al., 1996; Magnússon and Magnússon, 2000). The plots are sampled in alternate years. A few plots have been abandoned and new ones established due to loss to erosion or revision of methods (see Magnússon et al., 2009). In 2012, there were 25 plots operational on the island (Fig. 2).

In 2013, the study was extended to two of the older volcanic islands of the archipelago, Elliðaey and Heimaey (Fig. 1). The aim was to investigate old grassland communities of the islands under different nutrient inputs from seabirds, as these grasslands are indicative of the future development on Surtsey. Two accessible islands and areas with limited human disturbance were selected. The number of plots was determined by the available time and manpower, and was considered as an absolute minimum for a comparison to the Surtsey plots. Permanent plots, identical to the Surtsey plots, were established on each island and sampled in the same way in the middle of July. The four Elliðaey plots were set up within puffin colonies with high nutrient inputs from sea to land (Table 1), where soil depth was $>1 \mathrm{~m}$ on a palagonite tuff slope (one plot) and cinder crater slopes (three plots) dating from 5000-6000 years ago (Sigurðsson and Jakobsson, 2009). Similarly, four plots were set up on Heimaey, on palagonite tuff slopes with $>1 \mathrm{~m}$ soil depth, in a small enclosed valley on the southern part of the island (Fig. 1). The eruption, during which the valley was created, also dates from 5000 to 6000 years ago. Since the valley does not open out to the ocean, it has probably never been a seabird breeding site and thus it was not expected to be impacted by high nutrient input from seabirds, as the Elliðaey plots are (Table 1).

\subsection{Vegetation, soil and plant biomass}

The permanent plots are $10 \times 10 \mathrm{~m}$ in size, and were sampled with line transects (Magnússon et al., 2009). Five parallel $10 \mathrm{~m}$ transects were laid across each plot, at a distance 
Table 1. Permanent plots on Surtsey (S) in 2012, Elliðaey (E) and Heimaey (H) in 2013, year of establishment, substrate type and influence of seabirds. The plots on Elliðaey and Heimaey have thick (> $1 \mathrm{~m})$, developed soils on top of substrate.

\begin{tabular}{|c|c|c|c|}
\hline $\begin{array}{l}\text { Plot } \\
\text { no. }\end{array}$ & $\begin{array}{l}\text { First } \\
\text { sampling }\end{array}$ & $\begin{array}{l}\text { Substrate } \\
\text { type }\end{array}$ & $\begin{array}{l}\text { Seabird } \\
\text { influence }\end{array}$ \\
\hline $\mathrm{S} 1,3,4$ & 1990 & Sandy sheet lava & High \\
\hline S6-10 & 1994 & Sheet lava & High \\
\hline S22, 23 & 1995 & Sheet lava & Moderate \\
\hline S11-14, 16, 18-21 & 1994, 1995 & Sandy sheet lava & Low \\
\hline S15, 17 & 1994 & Tephra hill slopes & Low \\
\hline $\mathrm{S} 29,30$ & 2005 & Coastal sand & Low \\
\hline $\mathrm{S} 31,32$ & 2008 & Block lava & Low \\
\hline E1-4 & 2013 & Cinder \& palagonite hill slopes & High \\
\hline $\mathrm{H} 1-4$ & 2013 & Palagonite hill slopes & Low \\
\hline
\end{tabular}



Figure 2. Location of permanent plots on Surtsey, infrared Rapid Eye image from 28 August 2012. Note dense vegetation of gull colony (13 ha) on the southern lava and shore community (1 ha) on the northern spit. Plots 1, 3, 4, 6-10 and 23 are within the gull colony.

of 1, 3, 5, 7 and $9 \mathrm{~m}$ from their edge. Plant cover was determined by a line-intercept method; all vascular plants were recorded separately for each metre along the line. Additional species within the plots not intercepted by the lines were also recorded and given an intercept value of $1 \mathrm{~cm}$, equal to $0.02 \%$ cover.

Soil was sampled within the Surtsey plots in 1998 and again in 2008 (Magnússon et al., 2009). In the latter sampling, four random samples $(7 \mathrm{~cm} \mathrm{dia} \times 10 \mathrm{~cm}$ depth) were taken from each plot and mixed for a composite sample. In the laboratory, the samples were sieved through a $2 \mathrm{~mm}$ mesh for determination of $\mathrm{pH}$, total organic carbon (C) and nitrogen $(\mathrm{N})$, carried out by the Centre of Chemical Analyses (Efnagreiningar Keldnaholti), ICETEC, Reykjavík, Iceland. Details are further described in Magnússon et al. (2009). Soil samples of plots in Elliðaey and Heimaey were sampled to a $10 \mathrm{~cm}$ depth in three locations per plot. The samples were sieved through $2 \mathrm{~mm}$ mesh, ground to powder and total $\mathrm{C}$ and $\mathrm{N}$ analysed by dry combustion with an NC2100 C / N analyser (Carlo Erba Instruments, Italy) at the University of Antwerp, Belgium. Only the C data from Surtsey 2008 and Elliðaey and Heimaey in 2013 are dealt with here.

Plant biomass has, since 1999, been harvested from the Surtsey plots every fourth year (Magnússon et al., 2009), the last sampling occurring in 2011. The sampling was destructive and carried out in a $10 \times 10 \mathrm{~m}$ area adjacent to each permanent plot. Four samples were harvested at random coordinates, and the vegetation was cut at ground level along a $2 \mathrm{~m}$ line using electric grass clippers with a 7.5 or $9.5 \mathrm{~cm}$ wide cut. All vegetation was collected. The samples were dried at $60{ }^{\circ} \mathrm{C}$ to constant oven-dry weight.

\subsection{Density of seabird nests}

Since 2003, density of seabird nests (mainly seagulls) around the permanent plots on Surtsey has been determined annually. A $1000 \mathrm{~m}^{2}$ circular plot with a centre in the middle of a permanent plot was inspected, and nest bowls occupied in the current season counted. The lesser black-backed gull (Larus fuscus), great black-backed gull (L. marinus) and herring gull (L. argentatus) breed in substantial numbers upon the island. A few fulmar nests (Fulmarus glacialis) have also been encountered in the surveys and they were included (Magnússon et al., 2009). The plots on Elliðaey were within dense breeding colonies of puffins (Fratercula arctica). Nesting density was estimated according to methods of Hansen et al. (2011). The number of puffin burrows was counted in four $4 \times 4 \mathrm{~m}$ randomly placed subplots within or by each 
permanent vegetation plot. An average burrow-occupancy rate of $66 \%$ for Elliðaey in 2013 (Hansen, personal communication) was used to calculate nesting density.

\subsection{Invertebrates on Surtsey}

Invertebrate studies started on Surtsey in 1965 and were continued annually until 1984. Sampling was sporadic from 1985 to 2002, after which it recommenced and became an integral part of the biological studies. Sampling included pitfall trapping, netting and direct picking for different taxa. Most of the pitfall trapping was conducted in the permanent vegetation plots to relate the invertebrate communities to the vegetation and plant succession directly. In this paper, we used data of invertebrate catches in pitfall traps in the permanent plots on Surtsey from 2002 to 2006 (Ólafsson and Ingimarsdóttir, 2009).

\subsection{Data analysis}

Vegetation data (vascular plants only) sampled in the permanent plots in 2012 (Surtsey) and 2013 (Heimaey and Elliðaey) were analysed with detrended correspondence analysis (DCA; indirect ordination) and a two-way indicator species analysis (TWINSPAN; classification, Hill 1979a;b). The cover data were transformed $(\log +1)$ prior to analysis. In the ordination, rare species were down-weighted. In the classification the cut levels were set to $0,0.05,0.1,0.2$, $0.5,1.0$ and 1.5 after data inspection. The Shannon index of species diversity was calculated for all plots. Multivariate analyses were conducted with PC-ORD 6 (McCune and Mefford, 2011). One-way analysis of variance (ANOVA) on logtransformed values was used to determine significance of parameters for plots outside and inside the gull colony on Surtsey (JMP 6.0 package; SAS Inst., 2006). The variables were seabird nesting density, plant cover, species richness, plant diversity, plant biomass, soil carbon, invertebrate species richness, and invertebrate and Acari/Collembola catches. The same test was used to compare these characteristics of the TWINSPAN vegetation classes: plant cover, species richness, plant diversity, plant biomass and soil carbon.

\section{Results}

\subsection{Plant colonization on Surtsey}

The first species to colonize Surtsey in 1965 was the sea rocket (Cakile maritima), dispersed to the island by sea currents. The most recent colonizer is a wind-dispersed moonwort (Botrychium lunaria), first found in 2011. The total number of plant species that have established on the island at any time is 69 . In the 2013 expedition to the island, 59 of these were found (Fig. 3), but only 39 species appeared to have viable populations (Appendix A), defined as a population that has expanded or that occurs in at least five locations.

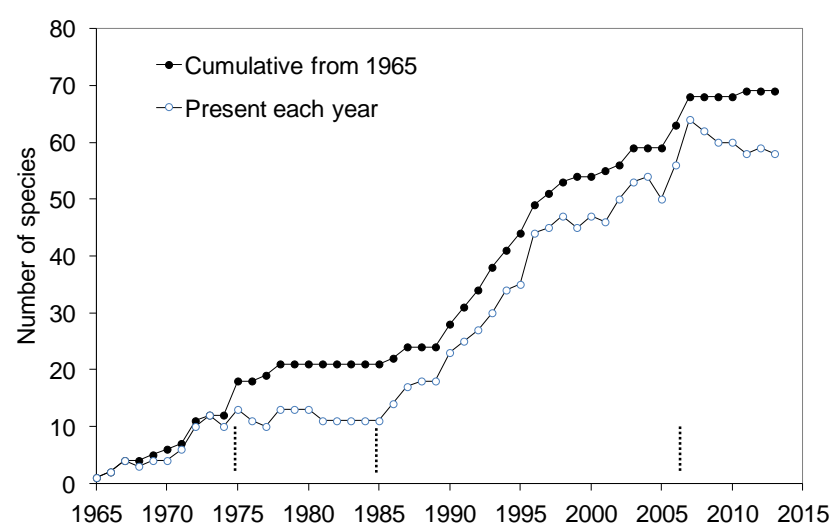

Figure 3. Surtsey colonization curve for vascular plants during the period 1965-2013. Vertical, dotted lines at bottom of diagram show divisions between the four main phases of colonization.

The plant colonization curve for the island over the first 50 years can be divided into four main periods (Fig. 3). The initial colonization of plants occurred during the first decade. These were mainly shore plants (Fig. 4) resulting from ocean dispersal and establishing on the infertile and sandy volcanic substrate of the island (e.g. Cakile maritima, Leymus arenarius, Honckenya peploides, Mertensia maritima). During this period, the first bird-dispersed (Cochlearia officinalis) and wind-dispersed species (Cystopteris fragilis) also colonized the island (Fig. 4). Most of the species were able to survive on the pristine island and start propagation. In the second period, between 1975 and 1985, colonization slowed and survival of newcomers was considerably lower than previously (Fig. 3). They were less well adapted to the harsh conditions than the pioneers. Only two of the species (Cerastium fontanum and Rumex acetosella), colonizing during this period, gained roothold and established. In the third period, between 1986 and 2007, a second wave of plant colonization occurred and survival of plants improved greatly. This was triggered by the establishment of a seagull breeding colony on the southern part of the island. The colony, which soon grew to 200-300 breeding pairs, became the locus of plant colonization. The gulls not only improved the nutrient status of the soil but also acted as agents of seed dispersal. Plants with higher nutrient demands now started to flourish and expand (e.g. Cochlearia officinalis, Stellaria media, Sagina procumbens, Tripleurospermum maritimum, Cerastium fontanum, Festuca rubra, Poa pratensis, P. annua, Ranunculus acris). Several years into this period, there was a pronounced increase in colonization of wind-dispersed species (Fig. 4). The soil amelioration brought about by the gulls opened a window for light-seeded (or sporophytic) species with limited seed reserves (e.g. Taraxacum spp., Leontodon autumnalis, Salix herbacea, S. phylicifolia, S. lanata, Platanthera hyperborea, Botrychium lunaria) to establish. In 2007, the number of species on the island peaked at 64 (Fig. 3). In the last period, 2008-2013, Surtsey suffered a net loss of 


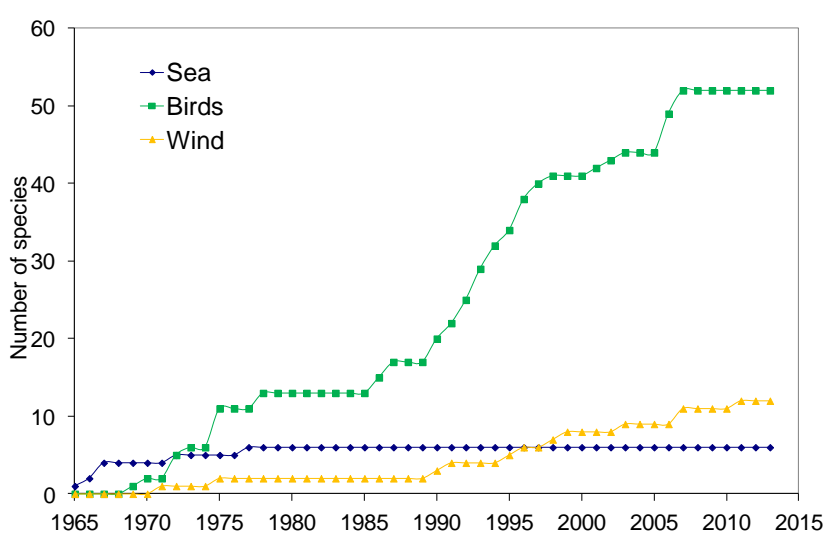

Figure 4. Cumulative curves of dispersal routes to Surtsey most probably used by different vascular plant species during the period 1965-2013. Based on dispersal-mode spectra of the flora and sites of establishment on the island.

plant species. Only one new colonizer was recorded, but all the lost species were very rare.

\subsection{Effects of seagulls on development on Surtsey}

During the period 2003-2012, gull nests were encountered in 10 of the permanent study plots, thereof nine within the main breeding area (Table 2). The total number of nests varied from 19 to 50 . The average number of nests in the 10 -year period was 3.9 within the breeding area. In plots outside it, only one nest was ever encountered, leading to an average of 0.01 (Table 2).

In 2012, there were 22 plant species recorded within the 25 permanent plots (Appendix A). Species with the highest relative frequency were Honckenya peploides, Sagina procumbens, Leymus arenarius and Cerastium fontanum, which occurred in over $50 \%$ of the plots (Fig. 5). The most notable changes since 2008 were the increases of Arabidopsis petraea and Silene uniflora, both of which established late but had reached a spreading phase. L. arenarius and C. fontanum had also increased considerably. Cochlearia officinalis had lost ground in 2012 and was only found in half of the plots in which it was recorded in 2008 (Fig. 5). Its main distribution was near the cliffs on the southern lava within the seabird colony, where grass swards and competition was increasing.

There was a great variation in the development of the plant cover, species richness and diversity in the permanent plots in 2012. This was reflected in the plant biomass and carbon status of soil (Table 2) from earlier sampling. Where breeding seabirds were absent or their impact low, the vegetation remained poorly developed. Average plant cover of plots outside the seabird colony in 2012 was $7.1 \%$ (Table 2), but most of the plots had $<5 \%$ cover. The cover was highest in the two plots with well developed shore community on the northern spit (Fig. 2). Average species richness of plots outside the gull colony was 4.4 (range $1-9$ ). The most common

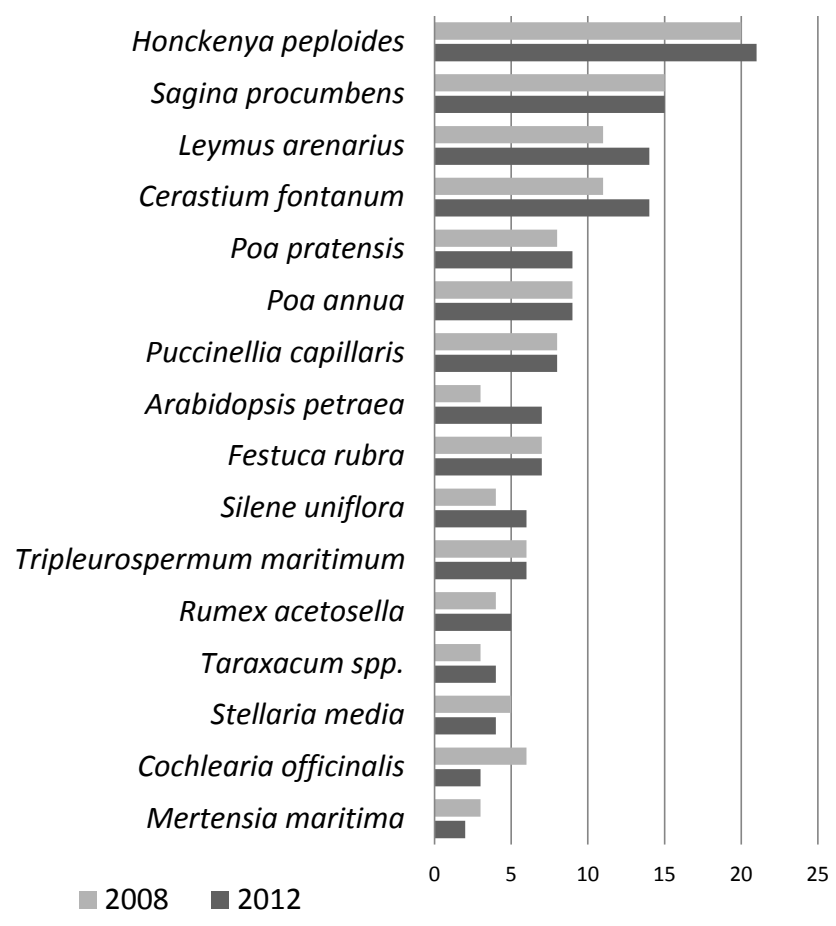

Figure 5. Relative frequency of vascular species in the 25 permanent plots on Surtsey in 2008 and 2012. Species occurring in $\geq 2$ plots are shown.

species were Honckenya peploides, Sagina procumbens, Leymus arenarius, Cerastium fontanum, Arabidopsis petraea, Poa апnиa and Silene uniflora. H. peploides had a mean cover of $5.0 \%$ and was the only species that had reached over $1 \%$ cover outside the gull colony (data not shown). In the plots within the gull colony, the average plant cover was $90.3 \%$ (Table 2). In four of the plots, the canopy had closed and layering of vegetation occurred. Average species richness of colony plots was 7.7 (range 7-12) in 2012. The most common species of the gull colony were Poa pratensis, Festuca rubra, Cerastium fontanum, Honckenya peploides, Leymus arenarius, Sagina procumbens, Tripleurospermum maritimum, Puccinellia capillaris, Stellaria media, Taraxacum spp., Cochlearia officinalis and Poa апnиа. It was $P$. pratensis and $F$. rubra that had gained the highest mean cover of $33.3 \%$ and $16.9 \%$ respectively. Six other species had reached over $1 \%$ mean cover within the seabird colony in 2012 (data not shown). Average plant species diversity (Shannon) in plots outside the seabird colony in 2012 was 0.5 , but 1.0 in plots within the colony (Table 2).

In 2011, mean plant biomass in plots outside the gull colony was $47 \mathrm{~g} \mathrm{dwt} \mathrm{m}^{-2}$. Biomass was highest in the northern spit plots, 29 and 30, which had dense cover of $H$. peploides. Within the colony, there was an average of $221 \mathrm{~g} \mathrm{dwt} \mathrm{m}^{-2}$ (Table 2). The peak biomass was in plots with dense grass swards of $L$. arenarius and $P$. pratensis (plots 1, 3 and 4). Topsoil in the permanent plots outside the gull 
Table 2. Surtsey permanent plot data. Average density of gull nests in plots on Surtsey, 2003-2012 (no. $/ 1000 \mathrm{~m}^{2}$ ), plant cover, species richness and diversity of vascular plants in 2012, standing biomass of vascular plants (live and dead) in 2011, and total carbon in top $10 \mathrm{~cm}$ of soil in 2008. Invertebrate and Acari/Collembola data are pitfall traps averages for the 2002-2006 sampling seasons, catch data are individuals caught. Means \pm s.e.; $p=$ ANOVA level of significance, n.s. $=>0.05 ; *=\leq 0.05: * *=\leq 0.01 ; * * *=\leq 0.001{ }^{*}{ }^{\mathrm{a}}$ Plots $11-22,29-32 ;{ }^{\mathrm{b}}$ plots 1, 3, 4, 6-10, 23; ${ }^{\mathrm{c}}$ include Coleoptera, Diptera, Hemiptera, Hymenoptera, Lepidoptera, Neuroptera, Thysanoptera, Araneae, Gastropoda and Oligochaeta. Invertebrates (including Acari/Collembola) were not sampled in plots 31 and 32, $n=14$.

\begin{tabular}{lrrl}
\hline & $\begin{array}{r}\text { Outside }^{\mathrm{a}} \text { gull } \\
\text { colony }\end{array}$ & $\begin{array}{r}\text { Inside }^{\mathrm{b}} \text { gull } \\
\text { colony } \\
n=16,14\end{array}$ & $p$ \\
& $n=9$ & \\
\hline Nests no. & $0.01 \pm 0.01$ & $3.9 \pm 0.8$ & $* * *$ \\
Plant cover \% & $7.1 \pm 2.8$ & $90.3 \pm 15.2$ & $* * *$ \\
Plant species richness & $4.4 \pm 0.5$ & $7.7 \pm 0.9$ & $*$ \\
Plant diversity (Shannon) & $0.5 \pm 0.1$ & $1.0 \pm 0.2$ & $*$ \\
Plant biomass g dw m ${ }^{-2}$ & $46.7 \pm 23.9$ & $221.2 \pm 75.6$ & $* *$ \\
Soil carbon \% & $0.05 \pm 0.02$ & $1.84 \pm 0.55$ & $* * *$ \\
Invertebrate species richness $^{\mathrm{c}}$ & $14.2 \pm 1.1$ & $28.3 \pm 1.3$ & $* * *$ \\
Invertebrate catch/day $^{\mathrm{c}}$ & $13.9 \pm 2.3$ & $17.7 \pm 2.9$ & n.s. \\
Acari/Collembola catch/day & $20.3 \pm 10.7$ & $108.4 \pm 13.4$ & $* * *$ \\
\hline
\end{tabular}

colony in 2008 had an average total carbon of $0.05 \%$, but $1.84 \%$ inside the colony (Table 2 ).

The invertebrate communities determined from the pitfall traps in the gull colony during the period 2002-2006 were richer in species and density than the barren areas were (Table 2). For the invertebrate groups that were identified to the species level, there were 28.3 species found on average within the gull colony plots, while only half of that was found in the plots outside the colony (Table 2). Total catches per day for these groups was, however, similar in the two areas (Table 2). Mites (Acari) and springtails (Collembola), which were dominant in the catches of the pitfall traps, were treated separately and joined into one group (Table 2). They were, however, not identified to a species level. In the sheer number of these animals, there was a great and significant difference between the two areas. In plots outside the gull colony, the average catch was 20.3 animals per day, which compares to 108.4 animals per day within the colony.

The gradual increase and expansion of dense vegetation of the gull colony has been monitored using aerial photographs and satellite images taken regularly of the island. The first signs of vegetation were visible on an aerial photo from 1988, approximately 3 years after the first nesting of the gulls. At that time, the area of the gull colony was only 0.03 ha in area. By 1998, it had increased to 6.6 ha and in 2012 the area had reached 12.1 ha, or over $9 \%$ of the island (Fig. 6).

\subsection{Comparison of vegetation development on Surtsey with neighbouring islands}

Multivariate classification and ordination were used to analyse resemblance of the young, developing vegetation of Surtsey in 2012 to the older grasslands of Heimaey and Elliðaey islands sampled in 2013. Four groups were formed by

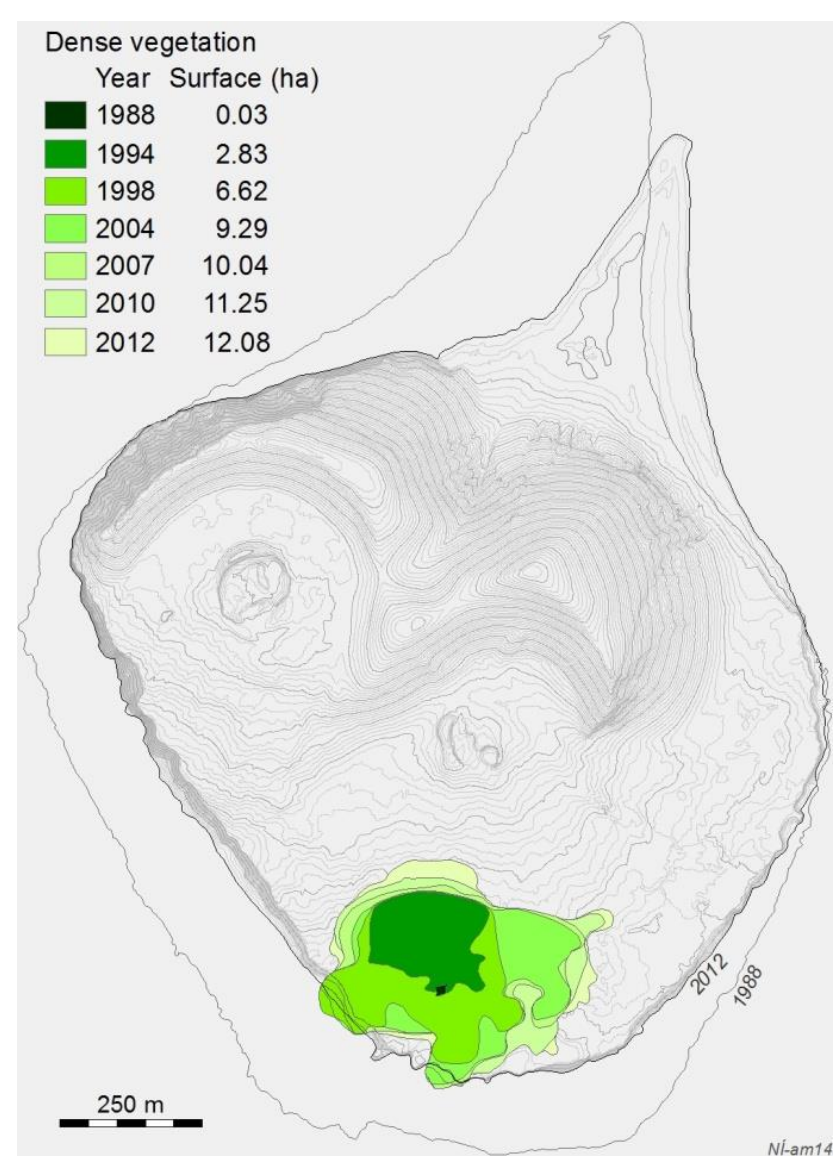

Figure 6. Expansion of dense vegetation within the Surtsey seagull colony during the period 1988-2012. Approximation from aerial and sattelite images, by Anette Th. Meier. Island outlines indicate erosion over the period. 
TWINSPAN (Fig. 7). A comparison of the groups showed their floristic, soils and density of seabird density differences (Table 3). The Heimaey grassland (group I), which lacks seabirds, had a moderate vascular plant cover, but it was not significantly different from the Elliðaey and Surtsey seabird plots (groups II and III; Table 3). The Heimaey grassland had the largest species richness and diversity. The top $10 \mathrm{~cm}$ soil of the Heimaey plots was relatively rich in carbon and similar to the Elliðaey and Surtsey seabird grasslands (Table 3). In the species-rich Heimaey grassland, there was an average of 18 species in each plot (Table 3). The dominant species in the cover were Festuca rubra (20.8\%), Agrostis capillaris (16.3\%), Ranunculus acris (11.5\%) and Anthoxantum odoratum $(8.2 \%)$.

The dense seabird grassland of Elliðaey and Surtsey (group II) had the highest plant cover, but low species richness and diversity. The average $\mathrm{C}$ content of soil was highest in this group (Table 3). On average, six species were found in the plots of group II (Table 3). Nesting density of puffins in the plots of Elliðaey was very high $\left(269\right.$ nests per $\left.1000 \mathrm{~m}^{2}\right)$, which compares to 5.1 gull nests per $1000 \mathrm{~m}^{2}$ in the Surtsey plots of the same group (Table 3). The Elliðaey puffin grassland consisted of only three species recorded in all plots and in significant quantities. The predominant species of the sward was Festuca rubra (67.2\%), followed by Poa pratensis $(18.4 \%)$ and the annual Stellaria media $(4.7 \%)$ which was found on the excavated soil around the puffin burrows. Three Surtsey plots of this group had a similar species composition to the Elliðaey grassland and a relatively high or developing cover of $F$. rubra and P. pratensis.

The third TWINSPAN group consisted of Surtsey plots from within or near the gull colony (Fig. 7). The vegetation of these plots was in transition from barrens to grassland. The nesting density was lower than in the Surtsey plots of group II, average plant cover was slightly lower, species richness and diversity a little higher, but they did not differ significantly (Table 3). C concentration of the soil was considerably lower than in the plots of groups I and II, but it was elevated from the plots of the Surtsey barrens in group IV, and the differences were significant (Table 3). The dominant species in the plots in group III were $P$. pratensis and $L$. arenarius in the sandy plots, but the lava plots were more variable with P. capillaris, S. procumbens, P. pratensis and F. rubra as the most common species (data not shown).

The fourth TWINSPAN group consisted of Surtsey plots, which were located outside the gull colony and in an early or static succession (Fig. 7). The plant cover of these plots was poorly developed, species richness and diversity low and the soil very poor in $\mathrm{C}$ (Table 3 ). These plots were all on sand/tephra substrate, with the exception of plots 31 and 32, which were on block lava (Fig. 2). H. peploides was the characteristic species of this group with an average cover of $6.7 \%$. All other species of this group had $<0.3 \%$ average cover.

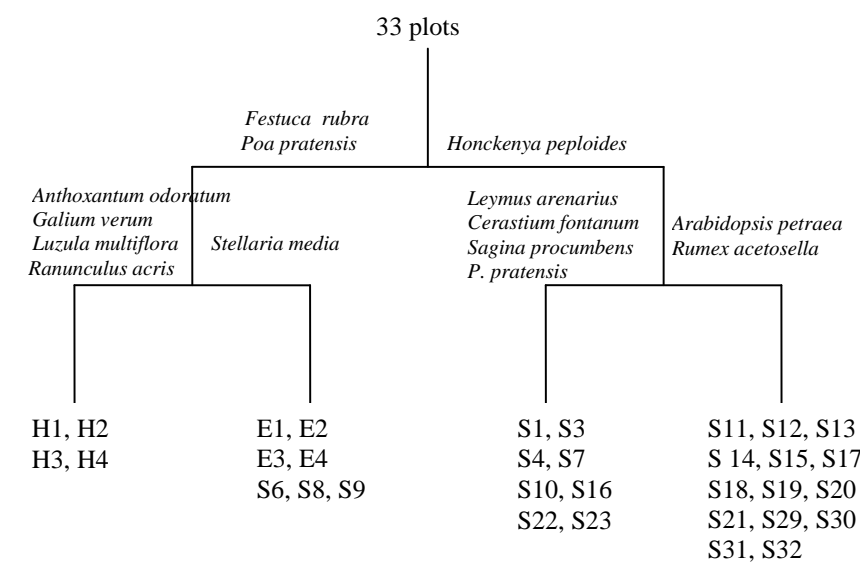

$\begin{array}{llll}\text { I } & \text { II } & \text { III } & \text { IV }\end{array}$

Figure 7. TWINSPAN-classification of permanent plots sampled on Surtsey (S), Heimaey (H) and Elliðaey (E) in 2012-2013. Species most decisive (indicators) of each division are shown and the four groups formed.

DCA ordination separated plots with dense grasslands, regardless of location, from poorly developed and barren Surtsey plots on the first axis (eigenvalue 0.791, gradient final length 6.172). Main separation along the second axis (eigenvalue 0.453 , gradient final length 4.077 ) was between sandy and lava plots on Surtsey (Fig. 8). The Heimaey plots formed a dense and distinct cluster of points on the left of the diagram, underlining the difference in vegetation composition from the Elliðaey and Surtsey plots. The Elliðaey plots were also in a dense cluster, as expected, but Surtsey lava plots (6 and 7) were the best developed $F$. rubra/P. pratensis swards were also here (Figs. 9-10). Furthest to the right and at the top of the diagram were Surtsey plots that were outside the gull colony with poorly developed vegetation (Fig. 8). On the right was a cluster of plots with mainly $H$. peploides, which develop into $P$. pratensis/L. arenarius grassland under the impact of seabirds and increased nutrient inputs, as shown in Surtsey plots 1, 3 and 4 (Fig. 9). At the top were barren lava plots with Sagina procubens and Pucinellia capillaris as pioneers, which develop towards F. rubra/P. pratensis grassland under increased nutrient inputs. The ordination showed that, as the succession progressed, under the influence of the seabirds, the vegetation of the sand and lava areas became more similar in composition than at the pioneer stages (Fig. 8).

\section{Discussion}

\subsection{Plant colonization on Surtsey}

The record of plant colonization of Surtsey and the probable routes of dispersal revealed show how the main vectors of immigration change during the ecosystem development on 
Table 3. Average density of seabird nests (no. $/ 1000 \mathrm{~m}^{2}$ ), plant cover, species richness and diversity of vascular plants, and soil carbon in plots sampled on islands, according to main TWINSPAN groupings; G: average density of gull nests on Surtsey 2003-2013; P. average density of puffin nests on Elliðaey in 2013. Means \pm s.e.; $p=$ ANOVA level of significance, n.s. $=>0.05 ; *=\leq 0.05: * *=\leq 0.01 ; * * *=\leq 0.001$. Means with same letter are not significantly different at $p=0.05$.

\begin{tabular}{|c|c|c|c|c|c|c|c|c|}
\hline Island & $\begin{array}{l}\text { Presence } \\
\text { of } \\
\text { seabirds }\end{array}$ & $\begin{array}{l}\text { TWINSPAN } \\
\text { group }\end{array}$ & $\begin{array}{l}\text { No. } \\
\text { of } \\
\text { plots }\end{array}$ & $\begin{array}{l}\text { Nesting } \\
\text { density }\end{array}$ & $\begin{array}{l}\text { Plant } \\
\text { cover } \\
\%\end{array}$ & $\begin{array}{l}\text { Species } \\
\text { richness }\end{array}$ & $\begin{array}{c}\text { Plant } \\
\text { diversity }\end{array}$ & $\begin{array}{c}\text { Soil } \\
\text { carbon } \\
\%\end{array}$ \\
\hline Heimaey & - & I & 4 & 0 & $69.20 \pm 16.34 a$ & $18.00 \pm 1.19 a$ & $1.90 \pm 0.22 \mathrm{a}$ & $6.23 \pm 1.47 \mathrm{a}$ \\
\hline Surtsey/Elliðaey & + & II & 7 & $5.13^{\mathrm{G}} / 269^{\mathrm{P}}$ & $88.42 \pm 12.25 \mathrm{a}$ & $6.00 \pm 0.90 \mathrm{~b}$ & $0.80 \pm 0.16 b$ & $9.14 \pm 1.11 \mathrm{a}$ \\
\hline Surtsey & + & III & 8 & $2.51^{\mathrm{G}}$ & $70.99 \pm 11.55 \mathrm{a}$ & $7.13 \pm 0.84 b$ & $0.85 \pm 0.15 b$ & $1.07 \pm 1.04 \mathrm{~b}$ \\
\hline Surtsey & - & IV & 14 & 0 & $7.56 \pm 8.73 b$ & $4.43 \pm 0.64 b$ & $0.54 \pm 0.12 b$ & $0.04 \pm 0.79 c$ \\
\hline$p$ & & & & n.d. & $* * *$ & $* * *$ & $* * *$ & $* * *$ \\
\hline
\end{tabular}

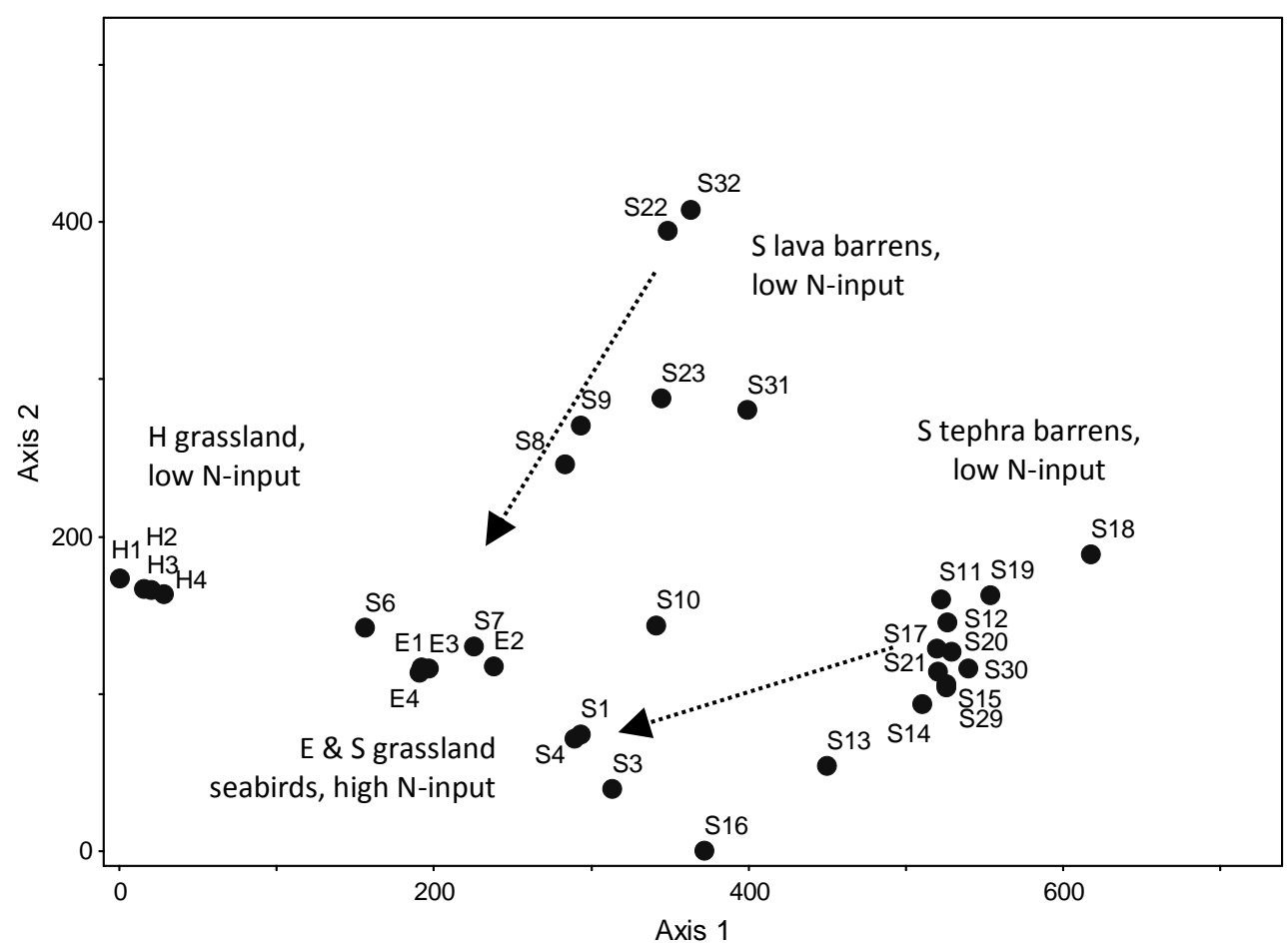

Figure 8. DCA-ordination results for permanent plots sampled on Surtsey (S), Heimaey (H) and Elliðaey (E) in 2012-2013. Arrows indicate direction of succession on Surtsey under nutrient inputs from breeding seagulls, axes units are multiplied by 100 .

the island. Of the 69 plant species found on the island since 1965 , about $75 \%$ have been dispersed by birds, $15 \%$ by wind and $10 \%$ by the sea. During the first years, shore plants dispersed by the sea were the main pioneers on the island. These plants had relatively large seeds, rich in reserves, enabling them to establish on nutrient poor, sandy substrates. In the case of Surtsey, the distance from the source on the nearby islands and the mainland is only a few to tens of kilometres so the chances of floating seeds ending upon the shores of Surtsey were high. New species dispersed by the sea have not been found on Surtsey after 1977 (Fig. 4). However, two of the species (Cakile and Atriplex), both annuals, did not gain a roothold on the island following their first colonization (Magnússon et al., 2009).

The decrease in rate of plant colonizaton and relative stagnation during the period 1975-1985 was probably caused by poor soil conditions and limited influx of seeds of new plant species. The sudden increase of the seagulls and formation of their breeding colony in 1985 was followed by a second wave of plant colonization continuing for the next 20 years. Most of the new plant species were found within or at the edges of the colony, indicating that the seeds were, to a large extent, dispersed to the island by the gulls and that nutrient additions from the birds had brought about the necessary soil amelioration for the plants to establish and spread on the 


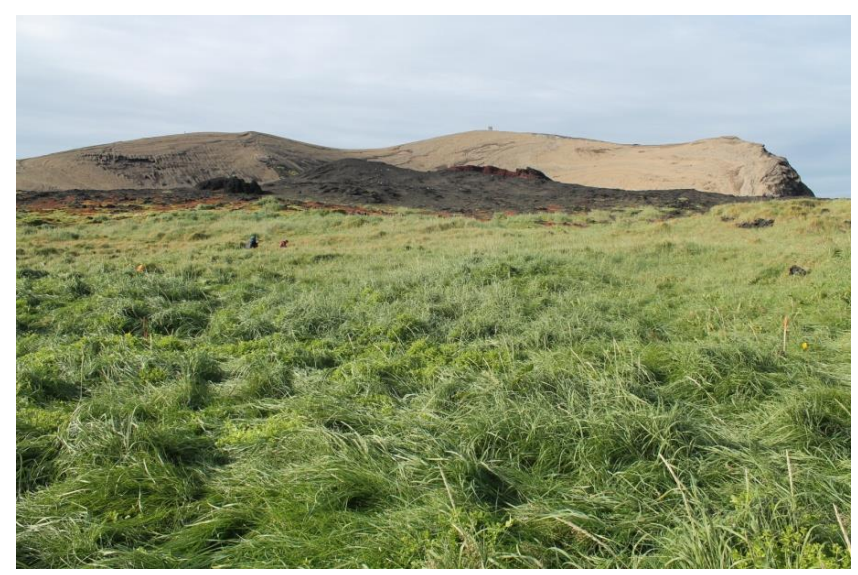

Figure 9. Poa pratensis/Leymus arenarius grassland in centre of gull colony (plot 1) on Surtsey in 2013. Upper-crater areas and palagonite ridges remain barren. Photo: BM.

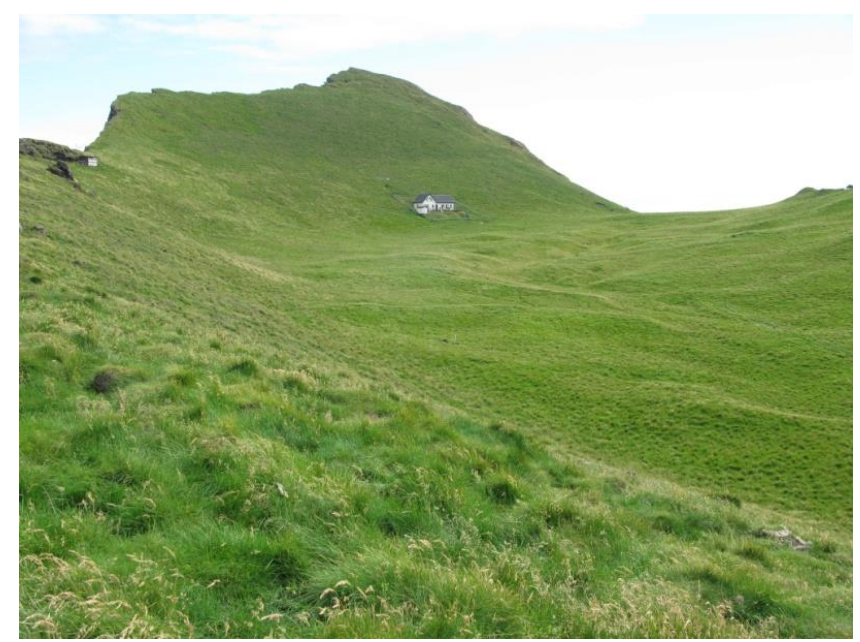

Figure 10. Festuca rubra/Poa pratensis grassland on upper parts of Elliðaey. Plot E1 was located in a puffin colony on the palagoninte ridge above and to the right of the cottage. Photo: BM, 2010.

island. Occurrence at the margins suggested that competition from established plants inhibit establishment of new arrivals. Dispersal of seeds to islands by gulls and other birds is reported in several studies (Nogales et al., 2001; Ellis, 2005; Abe, 2006; Aoyama et al., 2012). Most gulls are omnivorous, opportunistic feeders that use a variety of foods, including earthworms, berries and cereal grain. The presence of seeds in their diets is reported for many species (CalvinoCancela and Martin-Herrero, 2009; Calvino-Cancela 2011). Of the three large seagull species breeding on Surtsey, it is probably the lesser black-backed gull and the herring gull that have been the main agents of seed dispersal to the island. Both species are known to visit and feed in inland areas of the mainland, whereas the great black-backed gull is more confined to shore areas and depends more on marine food (Göt- mark, 1982; Magnússon et al., 2009). Other bird species may also have carried seed to Surtsey, e.g. snow buntings (Plectrophenax nivalis), greylag geese (Anser anser) and ravens (Corvus corax) that have frequented the island and bred in recent years (Magnússon et al., 2009; Petersen, 2009).

Wind-borne seeds and spores of various plant species must have rained over the island from its birth. It was, however, not until after 1990 that we saw a considerable increase in colonization of wind-dispersed species, a trend that still persists. This change is attributable to the improved soil conditions on the island following the gull invasion in 1985 . High-dispersal wind-borne species are known to have limited reserves and low tolerance of barren substrates, and they often require site amelioration prior to establishment (Wood and del Moral, 1987). Among the wind-borne species entering Surtsey after 1990 are three species of willows (Salix), an orchid (Platanthera hyperborea) and a small fern ally (Botrychium lunaria), which either grow in association with or require mychorrhizal fungi for germination and establishment (Schmid and Oberwinkler, 1994; Chadde and Kudray 2001; Thornton, 1996; Eyjólfsdóttir, 2009). Hence, the late establishment of these species may partly have been caused by a lack of the fungi in the early years. The shifting pattern of dispersal routes and their relative importance during the first 50 years of colonization on Surtsey has some similarities to the plant dispersal spectra obtained from other volcanic islands, e.g. Krakatau (Whittaker et al., 1992; Thornton, 1996), Anak Krakatau, (Partomihardjo et al., 1992) and Long Island volcano (Harrison et al., 2001; Thornton et al., 2001). They show importance of sea-dispersal at the early stages, but animal- and wind-dispersal patterns are more variable.

The halt in colonization of new species and a net loss of species on Surtsey after 2007 may indicate that competition is increasing in the community with denser swards and that most of the likely colonists have already arrived. A comparison of the flora of Surtsey with the other outer islands of the Vestmannaeyjar archipelago (Friðriksson and Johnsen, 1967) shows that, in the 50 years, all the common species of the other islands have been dispersed and established on Surtsey and that most of them have formed viable populations (Appendix A). The flora of Surtsey is by far the richest of any of the islands, explicable by its larger size, greater habitat diversity, more open swards and the absence of sheep grazing. Many of the plants confined to Surtsey are species of open shores, sands and tephra plains that no longer occur on the older islands.

\subsection{Effects of seagulls on development on Surtsey}

This study shows that the seagulls have had pronounced effects on vegetation and soil development. This was also reflected in the invertebrate fauna. The birds have thus jumpstarted the ecosystem buildup (Sekercioglu, 2006). At the nesting sites, the birds deposit faeces and regurgitate pellets, fish and marine invertebrates are spilled on the ground, 
feathers are shed and corpses of birds that die decompose. Of greatest importance for the soil enrichment and vegetation development are the faeces that have a relatively high content of nitrogen, phosphorus, potassium and minerals (Sobey and Kenworthy, 1979; Bancroft et al., 2005), which are of great importance in primary succession (Walker and del Moral, 2003). In an earlier account (Magnússon et al., 2009), we estimated, from nesting density and other studies (Hahn et al., 2007), that annual nutrient inputs from gulls in the Surtsey colony were about $25 \mathrm{~kg} \mathrm{~N} \mathrm{ha}^{-1}$. A new study of the soil development on the island, however, indicates that the average annual input within the colony is $47 \mathrm{~kg} \mathrm{Nha}^{-1}$, while the background atmospheric $\mathrm{N}$ deposition is only ca $1.2 \mathrm{~kg} \mathrm{~N} \mathrm{ha}^{-1}$ (Leblans et al., 2014). The nutrient enrichment of soil from the seagulls on Surtsey has had cascading effects on plant populations, invertebrates and land-bird colonization on the island (Magnússon et al., 2009; Ólafsson and Ingimarsdóttir, 2009; Petersen, 2009), similar to the nitrogenfixing lupins on Mount St. Helens (del Moral and Rozzell, 2005; del Moral, 2009; del Moral and Magnússon, 2014). These observed patterns were extended in the present study.

In areas of the island outside the gull colony, the plant succession and soil development has remained slow (Magnússon et al., 2009). A gradual buildup has occurred (Stefansdottir et al., 2014), but rates of change are not comparable to the gull colony area (del Moral and Magnússon 2014, Leblans et al., 2014). The long-term monitoring of vegetation in permanent plots on Surtsey showed that it was mainly ruderal species (sensu Grime et al., 1988) that initially responded to the increased nutrient inputs from the gulls, leading to an abrupt increase in species richness and diversity of the vegetation (Magnússon et al., 2009). With further development, these species have, however, lost ground to more competitive, rhizomatous grass species of greater longevity that have become dominant in the vegetation in the oldest part of the gull colony. A decline in species richness and diversity has occurred during this development.

The invertebrate fauna of areas outside the gull colony was characterized by low species richness and catches of animals. Dipterans were the majority of species caught; however, most of them derived from the gull colony area (Ólafsson and Ingimarsdóttir, 2009). Within the gull colony, the invertebrate fauna showed a considerable change in ecosystem structure and function. The high catches of mites (Acari) and springtails (Collembola) are indicative of denser vegetation and greater decomposition activity (Swift et al., 1979). These animals are an important source food for larger invertebrates, such as staphylinid beetles and linyphiid spiders which were abundant in the gull colony (Ólafsson and Ingimarsdóttir, 2009). In the dense vegetation plant feeding invertebrates had colonized and started to thrive, such as root feeding dipterans, saprophagous dipterans and plant feeding lepidopterans. Several species of parasitic hymenopterans had also become a part of the invertebrate community of the gull colony, but their main hosts are dipteran and lepidopteran larvae and aphids (Ólafsson and Ingimarsdóttir, 2009). Colonization of some of the bird species on Surtsey was dependant on the developing vegetation and invertebrate fauna of the gull colony. In 1996, 10 years after the formation of the colony, snow bunting (Plectrophenax nivalis) became the first land bird to breed on the island (Magnússon and Ólafsson, 2003). At that time, the dense vegetation of the gull colony had extended to ca. 5 ha. After 2000 two other passerines, the pied wagtail (Motacilla alba) and the meadow pipit (Anthus pratensis), also started breeding (Magnússon et al., 2009; Petersen, 2009). These three passerine species are dependant on insects for raising their young and their main source of food is within the gull colony (Ólafsson and Ingimarsdóttir, 2009). Studies of invertebrate colonization of young volcanic islands and nunataks have shown that at the early stages allochthonous inputs or littoral debris are important sources for pioneering communities consisting of heterotrophic scavenging detrivores and predators (Edwards and Thornton, 2001; Sikes and Slowik 2010; Ingimarsdóttir et al., 2013), not dependant on colonization by autotrophs (Hodkinson et al., 2002). This was also the case in the early years on Surtsey (Lindroth et al., 1973). Plant colonization and vegetation development is followed by further invertebrate colonization and diversification. However, it is characterized by relatively generalist species as colonization by specialists of later successional vegetation stages is harder (New and Thornton, 1992) and occurs on a different time scale.

\subsection{Vegetation development on Surtsey in comparison to neighbouring islands}

The vegetation of the older Vestmannaeyjar islands $(>5000$ years old) gives an insight into what will be the outcome of long-term succession on Surtsey. Although the grassland sites sampled on Heimaey and Elliðaey in 2013 are small and do not represent all the different conditions and plant communities of the islands (Friðriksson and Johnsen, 1967; Friðriksson et al., 1972a), they do provide a meaningful comparison and connection between the primary and mature stages in plant succession on these bird-impacted volcanic islands. The response of the different plant species to nutrient enrichment and early dominance of grasses in the bird colony on Surtsey is also of particular interest. The best developed grassland plots on Surtsey showed a strong affinity with the plots sampled in the puffin colonies on Elliðaey, which were also very species-poor, of low diversity and had Festuca rubra and Poa pratensis as dominant species. The high-breeding density of the puffins indicated that nutrient input from the seabirds on Elliðaey was several times higher than in the gull colony on Surtsey.

All the outer islands of the Vestmannaeyjar islands are impacted by seabirds and receive external nutrient inputs. Their vegetation has a greater resemblance with the puffin colonies of Elliðaey than the Heimaey grassland studied (Friðriksson and Johnsen, 1967; Friðriksson et al. 1972b). 
Our results showed that the Elliðaey puffin colonies had by far the richest soils in carbon, as well as nitrogen (Leblans, unpublished data). The Heimaey grassland, which has developed under limited nutrient input from seabirds, had, by contrast, high species richness and diversity in comparison to the Elliðaey/Surtsey seabird grassland. A study of vegetation, seabirds and the impact of introduced foxes on islands in the sub-arctic Aleutian archipelago in Alaska has demonstrated that, at high seabird densities, plant communites are graminoid dominated (Croll et al., 2005). On fox-infested islands with reduced seabird populations, abundance of grasses declined and the vegetation developed towards tundra, due to reduced marine nutrient inputs (Croll et al., 2005). Grasslands on fertile soils with high availability of nitrogen and phosphorus are known to be species-poor with low plant diversity (Janssens et al., 1998). In their experimental study of a Festuca rubra grassland in central Europe, Pavlu et al. (2012) found that, at high doses of $\mathrm{N}$ and under no $\mathrm{P}$ and $\mathrm{K}$ limitations, a substantial decline in species richness occurred. The trends observed in the grassland developing on Surtsey and the contrasts between the grasslands of Elliðaey and Heimaey under different seabird impacts are similar to the findings of these grassland studies.

\section{Conclusions}

Over the first 50 years, seagulls were the main agents of ecosystem development on Surtsey through seed-dispersal to the island and nutrient transfer from sea to land. In areas impacted by the gulls, productive, species-poor grassland has developed on relatively rich soils, high in invertebrate abundance and with breeding insectivorous birds. Continued breeding of the seagulls, colonization of puffins and other seabirds will lead to further development of the grassland. Due to erosion, the island will eventually lose its lower sandy and lava habitats with the associated flora and fauna. The bird colonies will concentrate on the upper part of the island, where grassland will develop, as on the older neighbouring islands. 


\section{Appendix A}

Table A1. Vascular plants colonizing Surtsey during the period 1965-2013 and species list for neighbouring Vestmannaeyjar islands; (•) denotes species that have been recorded on Surtsey but were not present in 2013; species that had formed viable populations (v.p.) in 2013 or were found within permanent plots (p.p) in 2012 are marked. The species list of the Vestmannaeyjar islands is based on Friðriksson and Johnsen 1967, and our surveys of Elliðaey and Álsey in 2010-2013.

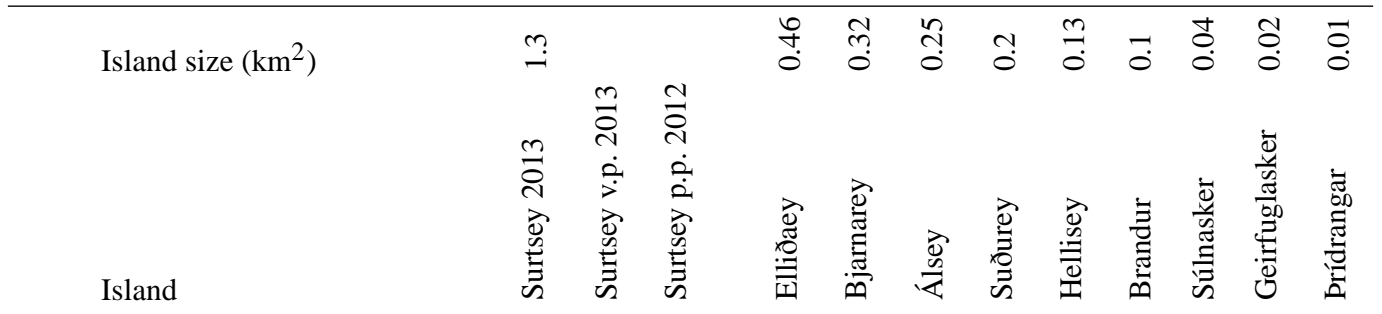

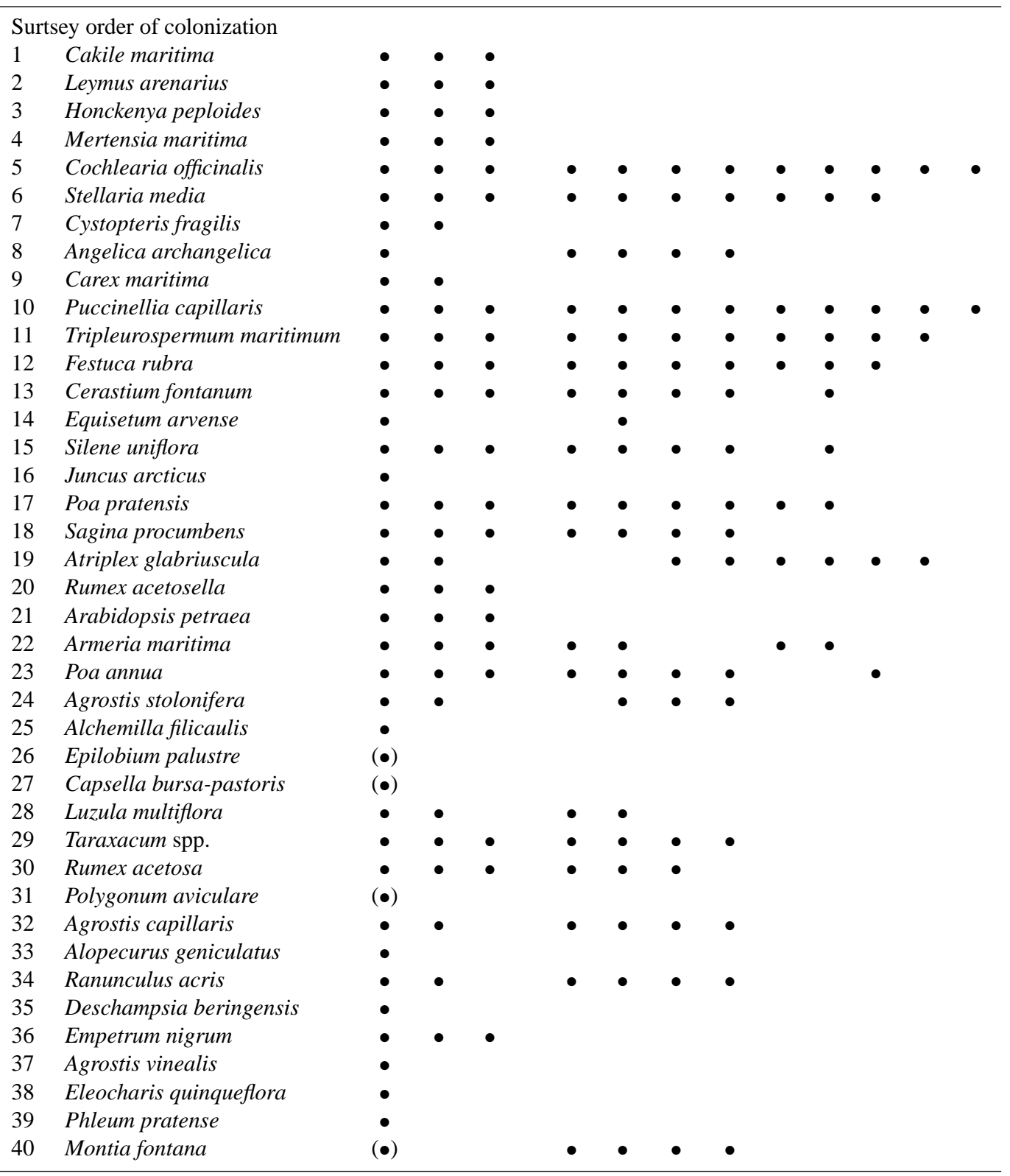


Table A1. Continued.

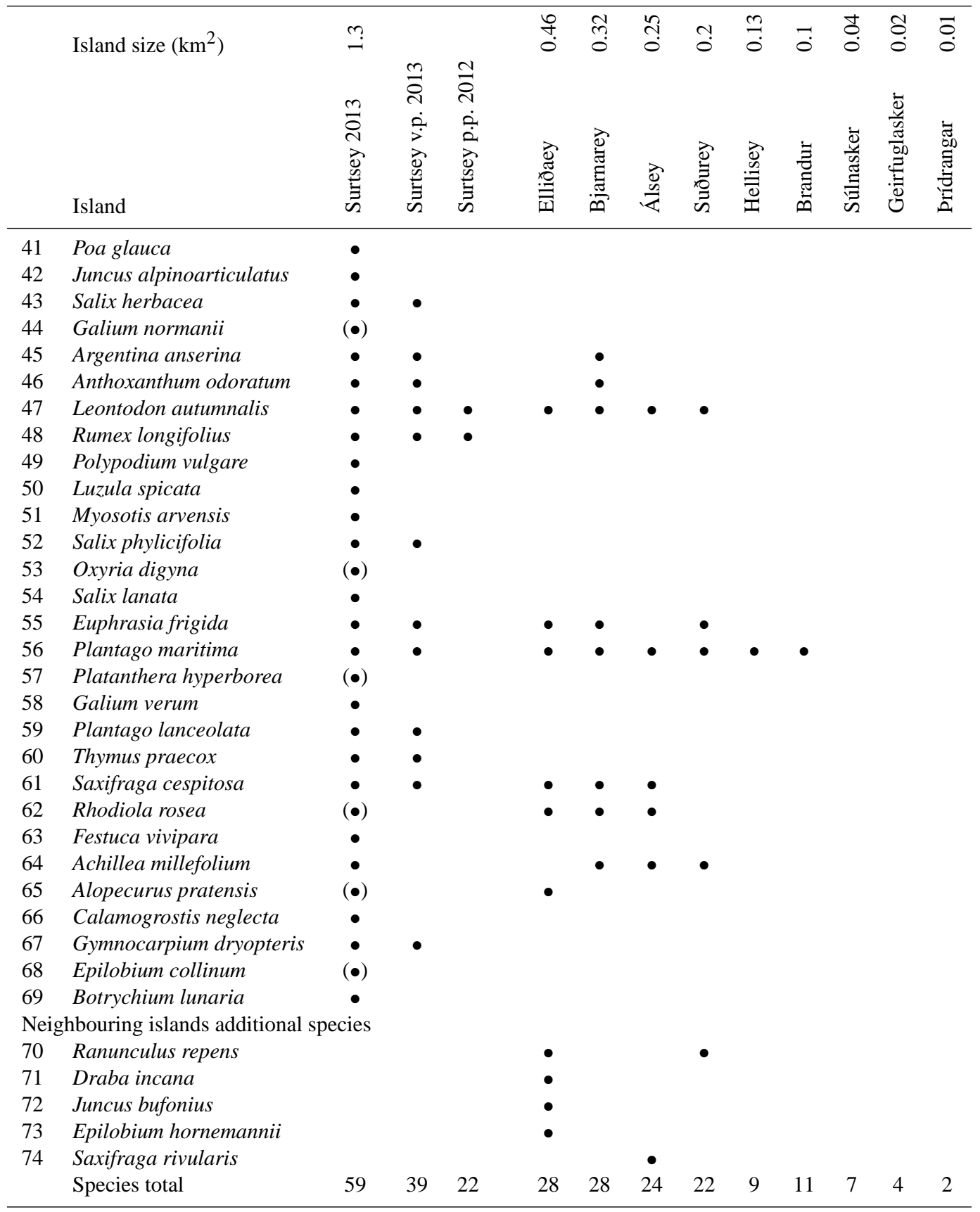


Acknowledgements. The Surtsey Research Society has provided logistic support for the study, and transport to the island was in the hands of the Icelandic Coastguard. The project was initially funded by the Icelandic Research Council (grant 944180094), Toyota Iceland supported biological research of IINH on the island in 2007 and 2008. Anette Th. Meier and Sigmar Metúsalemsson assisted with diagrams and maps, Járngeður Grétarsdóttir and Hafdís Hanna Ægisdóttir sampled vegetation and Niki Leblans soils and analysed carbon of plots on Elliðaey and Heimaey, Marinó Sigursteinsson, Ingvar Atli Sigurðsson, Erpur Snær Hansen and Páll Marvin Jónsson assisted with logistics and transport during the Elliðaey expeditions, several others have participated on Surtsey through the years, not least Sturla Friðriksson, who lead ecological research on the island for decades and, Roger del Moral made valuable comments on and improvements to the manuscript.

Edited by: T. New

\section{References}

Abe, T.: Coloninization of Nishino-shima Island by plant and arthropods 31 years after eruption, Pacific Sci. 60, 355-365, 2006.

Aoyama, Y., Kawakami, K., and Chiba, S.: Seabirds as adhesive seed dispersers of alien and native plants in the oceanic Ogasawara Islands, Japan, Biodivers. Conserv. 21, 2787-2801, 2012.

Arnalds, O.: The influence of volcanic tephra (ash) on ecosystems, Adv. Agron. 121, 332-380, 2013.

Astthorsson, O. S., Gislason, A., and Jonsson, S.: Climate variability and the Icelandic marine ecosystem, Deep-Sea Res., 54, 2456-2477, 2007.

Bancroft, W. J., Garkaklis, M. J., and Roberts, J. D.: Burrow building in seabird colonies: a soil-forming process in island ecosystems, Pedobiologia, 49, 149-165, 2005.

Bjarnason, Á. H.: Vegetation on lava fields in the Hekla area, Iceland, Acta Phytogeogr. Suec. 77, Uppsala, 110 pp., 1991.

British Ornithologists' Union (BOU): The British List: a checklist of birds of Britain, 8th Edn., Ibis 155, 635-676, 2013.

Calvino-Cancela, M.: Gulls (Laridae) as frugivores and seed dispersers, Plant Ecol., 212, 1149-1157, 2011.

Calvino-Cancela, M. and Martin-Herrero, J: Effectivenss of a varied assemblage of seed dispersers of a fleshy-fruited plant, Ecology 90, 3503-3515, 2009.

Chadde, S. and Kudray, G: Conservation Assessment for Botrychium lunaria (Common Moonwort), USDA Forest Service, Eastern Region, 38 pp., 2001.

Croll, D. A., Maron, J. L., Estes, J. A., Danner, E. M., and Byrd, G. V.: Introduced predators transform subarctic islands from grassland to tundra, Science, 307, 1959-1961, 2005.

Cutler, N.: Long-term primary succession: a comparison of nonspatial and spatially explicit inferential techniques, Plant Ecol., 208, 123-136, 2010.

Cutler, N. A., Belyea, L. R., and Dugmore, A. J.: Spatial patterns of microsite colonization on two young lava flows on Mount Hekla, Iceland, J. Veg. Sci. 19, 277-286, 2008.

Dale, V. H., Swanson, F. J., and Crisafulli, C. M.: Disturbance, survival, and succession: understanding ecological reponses to the 1980 eruption of Mount St. Helens, in: Ecological Responses to the 1980 Eruption of Mount St. Helens, edited by: Dale, V. H., Swanson, F. J., and Crisafulli, C. M., Springer, 3-11, 2005.

DeGange, A. R., Byrd, G. V., Walker, L. R., and Waythomas, C. F.: Introduction. The impacts of the 2008 eruption of Kasatochi volcano on terrestrial and marine ecosystems in the Aleutian Islands, Alaska, Arc. Antarc. Alp. Res., 42, 245-249, 2010.

del Moral, R.: Primary succession on Mount St. Helens, with reference to Surtsey, Surtsey Res., 12, 153-157, 2009.

del Moral, R. and Magnússon, B.: Surtsey and Mount St. Helens: a comparison of early succession rates. Biogeosciences, 11, 20992111, doi:10.5194/bg-11-2099-2014, 2014.

del Moral, R. and Rozzell, L. R.: Effects of lupines on community structure and species association, Plant Ecol., 180, 203-215, 2005.

Edwards, J. S. and Thornton, I. W. B.: Colonization of an island volcano, Long Island, Papua New Guinea, and an emergent island, Motmot, in its caldera lake. VI. The pioneer arthropod community of Motmot, J. Biogeogr., 28, 1379-1388, 2001.

Ellis, J. C.: Marine birds on land: a review of plant biomass, species richness and community composition in seabird colonies, Plant Ecol., 181, 227-241, 2005.

Eyjólfsdóttir, G. G.: Investigation of the funga of Surtsey 2008. Surtsey Res., 12, 105-111, 2009.

Eyjólfsson, G. Á.: Vestmannaeyjar. Árbók Ferðafélags Íslands 2009, edited by: Sigurðsson, J. V., Ferðafélag Íslands, Reykjavík, 319 pp., 2009.

Friðriksson, S.: Surtsey. Evolution of Life on a Volcanic Island, Butterworths, London, 198 pp., 1975.

Friðriksson, S.: Vascular plant on Surtsey 1991-1998, Surtsey Res., 11, 21-28, 2000.

Friðriksson, S. and Johnsen, B.: The vascular flora of the outer Westman Islands. Societas Scientarium Islandica, Section IV, 37-67, 1967.

Friðriksson, S. and Magnússon, B.: Development of the ecosystem on Surtsey with reference to Anak Krakatau, GeoJournal, 28.2, 287-291, 1992.

Friðriksson, S., Bjarnason, Á. H., and Sveinbjörnsson, B.: Vascular plants in Surtsey 1969, Surtsey Res. Progr. Rep. VI, 30-32, 1972a.

Friðriksson, S., Sveinbjörnsson, B., and Magnússon, S.: On the vegetation of Heimaey, Iceland, II, Surtsey Res. Prog. Rep. VI, 3653, $1972 b$.

Götmark, F.: Coloniality in five Larus gulls: a comparative study, Ornis Scandinav., 13, 211-224, 1982.

Grime, J. P., Hodgson, J. G., and Hunt, R.: Comparative Plant Ecology, Unwin Hyman, London, 742 pp., 1988.

Hahn, S., Bauer, S., and Klaassen, M.: Estimating the contribution of carnivorous water birds to nutrient loading in freshwater habitats, Freshw. Biol., 52, 2421-2433, 2007.

Hansen, E. S., Sigursteinsson, M., and Garðarsson, A.: Lundatal Vestmannaeyja (The breeding population size of Atlantic Puffin in Vestmannaeyjar, S-Iceland), Bliki 31, 15-24, 2011.

Harrison, R. D., Banka, R. Thornton, I. W. B., and Shaahan, M.: Colonization of an island volcano, Long Island, Papua New Guinea, and an ermergent island, Motmot, in its caldera lake. II. The vascular flora, J. Biogeogr., 28, 1311-1337, 2001.

Hill, M. O.: DECORANA - A FORTRAN program for detrended correspondence analysis and reciprocal averaging, Ecology and Systematics, Cornell Univ., Ithaca, New York, 52 pp., 1979a. 
Hill, M. O.: TWINSPAN - A FORTRAN program for arranging multivariate data in ordered two-way table by classification of individuals and attributes, Ecology and Systematics, Cornell University, Ithaca, New York, 48 pp., 1979 b.

Hilmarsson, J.Ó.: Fuglalíf Vestmannaeyja (Birdlife of Vestmannaeyjar), in: Vestmannaeyjar, Árbók Ferðafélags Íslands 2009, edited by: Sigurðsson, J. V., Ferðafélag Íslands, Reykjavík, 2873, 2009.

Hodkinson, I. D., Webb, N. R., and Coulson S. J.: Primary community assembly on land - the missing stages: why are the heterotrophic organisms always the first?, J. Ecol., 90, 569-577, 2002.

Ingimundardóttir, G. V., Weibull, H., and Cronberg, N.: Bryophyte colonization history of the virgin volcanic island Surtsey, Iceland, Biogeosciences, 11, 4415-4427, doi:10.5194/bg-11-44152014, 2014.

Ingimarsdóttir, M., Ripa, J., Magnúsdóttir, Ó.B. and Hedlund, K.: Food web assembly in isolated hatitats: A study from recently emerged nunatks, Iceland, Basic Appl. Ecol., 14, 174-183, 2013.

Jakobsson, S. P., Gudmundsson, G., and Moore, J. G.: Geological monitoring of Surtsey, Iceland 1967-1998, Surtsey Res. 11, 99$108,2000$.

Jakobsson, S. P., Magnússon, B., Ólafsson, E., Porvarðardóttir, G., Gunnarsson, K., Baldursson, S. and Petersen, Æ.: Nomination of Surtsey for the UNESCO World Heritage List, edited by: Baldursson, S. and Ingadóttir, Á., Icelandic Institute of Natural History, Reykjavik, 124 pp., 2007.

Janssens, F., Peeters, A., Tallowin, J. R. B., Bakker, J. P., Bekker, R. M., Fillat, F., and Oomes, M. J. M.: Relationship between soil chemical factors and grassland diversity, Plant Soil, 202, 69-78, 1998.

Kristinsson, H.: Checklist of the vascular plants of Iceland, Fjölrit Náttúrufræðistofnunar No. 51, 58 pp., 2008.

Kristinsson, H. and Heiðmarsson, S.: Colonization of lichens on Surtsey 1970-2006, Surtsey Res., 9, 81-104, 2009.

Leblans, N. I. W., Sigurdsson, B. D., Roefs, P., Thuys, R., Magnússon, B., and Janssens, I. A.: Effects of seabird nitrogen input on biomass and carbon accumulation after 50 years of primary succession on a young volcanic island, Surtsey, Biogeosciences Discuss., 11, 6269-6302, doi:10.5194/bgd-11-6269-2014, 2014.

Lindroth, C. H., Anderson, H., Bödvarsson, H., and Richter, S. H.: Surtsey, Iceland. The development of a new fauna 1963-1970, Terrestrial invertebrates, Ent. Scand. Suppl., 5, 1-280, 1973.

Magnússon, S. and Friðriksson, S.: Moss vegetation on Surtsey in 1971 and 1972, Surtsey Res. Progr. Rep., 7, 45-57, 1974.

Magnússon, B. and Magnússon, S. H.: Vegetation succession on Surtsey during 1990-1998 under the influence of breeding seabirds, Surtsey Res., 11, 9-20, 2000.

Magnússon, B. and Ólafsson, E.: Fuglar og framvinda í Surtsey (The colonization of Surtsey islands by birds and plants), Fuglar 2003, 22-29, 2003.

Magnússon, B., Magnússon, S. H., and Guðmundsson, J.: Gróðurframvinda í Surtsey. (Vegetation succession on the volcanic island Surtsey), Icel. Agr. Sci., 10, 253-272, 1996.

Magnússon, B., Magnússon, S. H., and Friðriksson, S.: Developments in plant colonization and succession on Surtsey during 1999-2008, Surtsey Res., 12, 57-76, 2009.
McCune, B. and Mefford, M. J.: PC-ORD. Multivariate Analysis of Ecological Data, Version 6. MjM Software, Gleneden Beach, Oregon, USA, 2011.

New, T. R. and Thornton, I. W. B.: Colonisation of the Krakatau Islands by invertebrates, GeoJournal 28.2, 219-224, 1992.

Nogales, M., Medina, F. M., Quilis, V., and González-Rodríguez, M.: Ecological and biogeographical implications of YellowLegged Gulls (Larus cachinnans Pallas) as seed dispersers of Rubia fructicosa Ait. (Rubiaceae) in the Canary Islands, J. Biogeogr. 28, 1137-1145, 2001.

Ólafsson, E. and Ingimarsdóttir, M.: The land-invertebrate fauna on Surtsey during 2002-2006, Surtsey Res., 12, 113-128, 2009.

Partomihardjo, T., Mirmanto, E., and Whittaker, R. J.: Anak Krakatau's vegetation and flora circa 1991 with observations on a decade of development and change, GeoJournal 28, 233-248, 1992.

Pavlu, V., Gaisler, J., Pavlu, L., Hejcman, M., and Ludvikova, V.: Effect of fertilizer application and abandonment on plant species composition of Festuca rubra grassland, Acta Oecologica, 45, 42-49, 2012.

Petersen, Æ.: Formation of a bird community on a new island Surtsey, Iceland, Surtsey Res., 12, 133-148, 2009.

SAS Institute: JMP version 6.03, Cary, NC, SAS Institute Inc., 2006.

Schmid, E., and Oberwinkler, F.: Light and electron microscopy of the host-fungus interaction in the achlorophyllous gametophyte of Botrychium lunaria, Can. J. Bot., 72, 182-188, 1994.

Sekercioglu, C. H.: Increasing awareness of avian ecological function, Trends Ecol. Evol. 21, 464-471, 2006.

Sigurðsson, I. A. and Jakobsson, S. P.: Jarðsaga Vestmannaeyja (Geological history of Vestmannaeyjar), in: Vestmannaeyjar, Árbók Ferðafélags Íslands 2009, 14-27, edited by: Sigurðsson, J. V., Ferðafélag Íslands, Reykjavík, 2009.

Sigurdsson, B. D. and Magnusson, B.: Ecosystem respiration, vegetation development and soil nitrogen in relation to breeding density of seagulls on a pristine volcanic island, Surtsey, Iceland, Biogeosciences, 7, 883-891, doi:10.5194/bg-7-883-2010, 2010.

Sikes, D. S. and Slowik, J.: Terrestrial arthropods of pre- and posteruption Kasatochi Island, Alaska, 2008-2009: a shift from a plant-based to a necromass-based food web, Arctic, Antarct. Alpine Res., 42, 297-305, 2010.

Sobey, D. G. and Kenworthy, J. B.: The relationship between herring gulls and the vegetation of their breeding colonies, J. Ecol. 67, 469-496, 1979.

Stefansdottir, G., Aradottir, A. L., and Sigurdsson, B. D.: Accumulation of nitrogen and organic matter during primary succession of Leymus arenarius dunes on the volcanic island Surtsey, Iceland, Biogeosciences Discuss., 11, 6591-6613, doi:10.5194/bgd11-6591-2014, 2014.

Svavarsdóttir, K. and Walker, L. R.: The value of Surtsey for ecological research, Surtsey Res. 12, 149-151, 2009.

Swift, M. J., Heal, O. W., and Anderson, J. M.: Decomposition in Terrestrial Ecosystems. Studies in Ecology Vol. 5, Blackwell Sci. Publ., 372 pp., 1979.

Thornton, I.: Krakatau. The Destruction and Reassembly of an Island Ecosystem, Harvard Univ. Press, 346 pp., 1996.

Thornton, I.: Island Colonization. The Origin and Development of Island Communities, Ecol. Rev. edited by: New, T., Cambridge Univ. Press, 287 pp., 2007. 
Thornton, I. W. B., Cook, S., Edwards, J. S., Harrison, R. D., Schipper, C., and Shanahan, M.: Colonization of an island volcano, Long Island, Papua New Guinea, and an ermergent island, Motmot, in its caldera lake. VII. The Overview and discussion, J. Biogeogr., 28, 1389-1408, 2001.

Walker, L. R. and del Moral, R.: Primary Succession and Ecosystem Rehabilitation, Cambridge Univ. Press, UK, 422 pp., 2003.
Whittaker, R. J., Bush, M. B., Partomihardjo, T., Asquith, N. M., and Richards, K.: Ecological aspects of plant colonization on the Krakatau islands, GeoJournal 28, 201-2011, 1992.

Whittaker, R. J., Triantis, R. J. and Ladle, R. J.: A general dynamic theory of oceanic island biogeography, J. Biogeogr., 35, $977-$ 994, 2008.

Wood, D. M. and del Moral, R.: Mechanisms of early primary succession in subalpine habitats on Mount St. Helens, Ecology 68, 780-790, 1987. 